\title{
Slaying the Monsters of Racism: A Geertzian Reading of Night of the Living Dead
}

\author{
Mengxi Chen \\ University of Southern California, Los Angeles, CA, U.S. \\ Email: 839923626@qq.com
}

\begin{abstract}
Religion and culture are interact with each other, and by the definition of Clifford Geertz, rituals can be expressed by quite a lot of ways in art. No one can doubt that in our world we are surrounded by religious symbols, which represent themselves via paintings, musics and movies. In this article, the author wants to elaborate how the horror movie, this unique movie genre, worked in illustrate social issues of civil rights movements of 1960s. In Night of the Living Dead, the zombies represent the middle class racism and the complacency about racism, which are indifferent and bloodthirsty. The dynamic process of killing the zombies presents the rituals of the U.S. that the heroes always conquer the evil. On the other hand, the evil always stands for the shortcoming of humans. The fighting between the righteous and the evil never stops.
\end{abstract}

Keywords: horror movie, religious ritual, social issues, civil rights movement, racism

\section{Introduction}

Sitting in the movie theater, you hear screaming. The monsters are unpredictable, and the creepy atmosphere really scares you and your friends. But after watching it, all of you forget the unhappy things. Horror movies help people to release their bad moods. The author thinks it is one of the reasons why horror movies are popular in the U.S. However, another reason also connects horror movies and people in the U.S. tightly. That is, the representative horror movies are religious based on the definition of rituals given by Clifford Geertz.

Geertz explains religion as deeply embedded in culture; it is an objective system of symbols. Horror movies are a part of popular culture of the U.S. I'd like to elaborate how the symbolic system matches with the horror movie genre, and the dynamic process, which points out how symbols seen in horror movies illustrate social issues. What are social issues? The 1960s were a time of civil rights movements and civil unrest. Middle class racism and complacency about racism can be seen in the films. The monsters are symbols of the conflict over some key American values.

There are mainly two kinds of evidences in support of my claim. On the one hand, killing the "sacred" monster is a ritual which represents a value of the U.S., because in most of the horror movies the righteous always conquer the evil in the end. Why is the monster sacred? Because the monster in horror movies is powerful and it reveals some shortcoming of humans. So it reinforced the old belief of most Americans in the U.S. that God blesses the good ones. On the other hand, the monster attacking humans is also in rituals, because it represents the topic our ancestors already told. That is, the world is dangerous, and humans can easily drop themselves into risky positions.

\section{Monsters as symbols}

"Sacred monsters" will never really disappear from our world. They are just hiding in the darkness. They watch people, and wait for a good time to attack. The monsters call people to fight together and to connect with each other tightly. No matter what ethnic groups people belong to and what customs they keep on, when monsters are attacking, people must forget their difference and confront monsters together. If humans refused to help each other, the outcome would be a disaster. Such as a plot is arranged in Night of the Living Dead: elder couple in the movie are indifferent for other people's life and stay in the cellar where they believe is the safest place. The plot is symbolized because it reveals the indifference of middle class Americans in 1960s. According to Raymond Firth, "religion is a form of human art." Horror movies embody the ritual battles between humans and monsters. Horror movies uncover the truth of mankind unpredictability. Furthermore, humans are surrounded by different types of dangerous factors. The only thing we can do is to be careful, and to refuse evil desires. Both humans killing the monsters and monsters attacking humans can be understood as ritual things, because killing and attacking are interactions between monsters and us.

The monsters, ghosts, and creepy characters in the horror movies represent a lot of things, because the horror movie 
as a genre of art, is a type of cultural representation of the U.S. "Like social forms, symbolic forms can serve multiple purpose." (Geertz, 113) The symbolic forms of monsters in horror films can serve the purpose of criticising social issues. So we should say thank you for these monsters etc. Let's call them sacred monsters. Firstly, sacred monsters can stand for humans' negative moods, such as angst, fear and so on. Secondly, sacred monsters represent humans' sins and shortcoming, such as ignorance, greed, lust, etc. Thirdly, sacred monsters convey the social issues which are associated with humans society, such as discrimination, racism, promiscuity, etc. The author thinks sacred monsters can be described as evil forces or negative side of the world. As Pals described in his book, "a culture is not just a set of elusive emotions or changeable impressions inside individual minds; it was something real and permanent — something objective — which has an effect on private emotions but maintains an existence apart from them." (Pals, 266) Geertz speaks of the objective existence of symbols like horror film monsters in this way, "Religion is a symbolic system, and symbols include images, behaviors, interactions, objects, events, etc, that can pass special meaning for someone." Sacred monsters are symbols of negative elements surround us. Cinematic killing zombies are the symbolic actions. I think rituals of killing use monsters as symbols. Cinematic killing in horror movies is done in a ritualized way. It is ritualistic. Geertz claims that religious symbols convey meaning. His essay "Thick Description: Toward an Interpretive Theory of Culture" shows how symbols convey meaning to humans. Thus a Geertzian reading of horror movie would say that these monsters are conveying meaning and messages to us in the movie. Sacred monsters are waiting for their audiences in the movie to give a lesson about real life. So the meaning behind monsters and the significance of monsters are vital important. Let's see how zombies in Night of the Living Dead revealed the significance and the meaning of the social issues.

Religious perspective differs art in that instead of effecting a disengagement from the whole question of factuality, deliberately manufacturing an air of semblance and illusion, it deepens the concern with fact and seeks to create an aura of utter actuality. (Geertz, 112)

I think these sentences explained why the monsters in horror films reflecting the social issues is a sort of religious perspective. Symbolic art forms in horror movies create an aura of factuality to make audiences feeling and thinking. Also, the symbolic behaviors of humans and monsters in horror movies generated rituals due to their behaviors recited the battles between humans and evil forces.

Even if that form be hardly more than the recitation of a myth, the consultation of an oracle, or the decoration of a grave - that the moods and motivations which sacred symbols induce in men and the general conceptions of the order of existence which they formulate for men meet and reinforce one another. (Geertz, 112)

\section{Night of the Living Dead - monsters as symbols of the conflicts over black power movements in the $1960 \mathrm{~s}$}

Here, I will give a brief introduction for the movie. The story begins with young rich class Barbra and her brother Johnny. An unnamed monster kills Johnny but Barbra escapes from it. Then Barbra hides in a farmhouse and meets with the other six people. Tom and Judy, the young working class couple; Karen Coopers and her parents, the elder couple in the house; the last one, black protagonist Ben. The monsters are attacking the farmhouse, and the people inside the house are somehow self-interested. Karen Coopers is bate by zombies outside, and her parents refused to find medicine care for her, but Tom, Judy and Ben go outside and try to save Karen. Unfortunately, Tom and Judy died outside, and Coopers lock the door when Ben goes back. Karen turns into a zombie and eats her parents. Ben killed Karen and also Coopers. But when zombies eliminated by government army, Ben is killed by mistake of the army.

"Much of the violence and organized protest of the 1960s arose, basically, from moral indignation, from a deep suspicion of established institutions, and from a demand for more exalted grounds of action than social success, business profits, and national self-interest." (Ahlstrom, 199)

During 1960s, the U.S. was in an atmosphere of upset. The upset came from different reasons, Vietnam war, the war for civil rights, and the indulgence of the young people. Till late 1960s the U,S. not only confronted the international pressure due to the decision of joining in Vietnam war, but also had to deal with the black freedom movements. "Social unrest proliferated as distraught populations protested against the

Vietnam War, repressive government policies, and a rising tide of racism and sexism." (Sanjek, 117) This is the situation of the U.S. society when Night Of the Living Dead was released by 1968. George Romero's Night of the Living Dead embodied the complacency of middle class, and their indifference about civil rights for African Americana. The film was a documentary style which horrified the audiences in 1968, and it was criticized due to the gore and the bloody scenes. The director used this style to make the scenes looked realistic. After 30 years Night of the Living Dead was selected to National Film Registry, because this film contained true echoes for 1960s. Night of the Living Dead not only had an 
advanced aesthetic significant, but also had cultural and historical perspective on the certain chaos of the society. In other words, Night of the Living Dead was a film to record in the national films list because the film reflected the social issues in turning these issues into "monsters". In the film, the monsters are not only the characters who are dead but somehow alive — the living deads, but also all of the less virtuous characters in the film. Many of the seemingly normal characters in the film are so selfish and weak that they border on the monstrous. "The film's victims in several cases became themselves monsters, thereby muddying the distinction between the monstrous and the normal as well as locating terror in the everyday world." (Sanjek, 111)

The beginning of the film is a scene of Barbra and her brother (Johnny). They go to visit their father's grave. Johnny tries to scare Barbra by saying "They are coming to get you!". Never imaged, it becomes a nightmare for Barbra and the audiences because sooner the zombie comes and kills Johnny. Following Johnny's dead, Barbra runs to a farmhouse and meets Ben and other five characters in the film. A large group of zombies surrounds the seven people and attack them. Barbra and her brother represents the rich young generation, they were well educated and innocent, but both of the two persons bite by zombies. We can imagine they were supposed to turn into zombies.

Romero, the director, arranged Barbra and her brother to represent the second generation of the upper class Americans, but in the film, both of them sacrificed for the living dead. They need protection of the other groups and cannot figure out who were helping them and who were pushing them into dangerous circumstance at the moments.

There were two couples in Night of the Living Dead. Before I talk about death of Coopers, I must refer to another couple in the movie, they are Tom and Judy. In Night of the Living Dead they were killed in the blast and then the living deads eat them up. Tom and Judy want to help Ben to get his truck, because Karren, Coopers' daughter was bate by zombies. Although Judy and Tom are not as rich as Barbra and Coopers, they are righteous and win sympathy for the other victims in the house. Also, they are young generation of the U.S. but not as rich as Barbra. I think the evidence is that Barbra and her brother drive a luxurious car but Tom and Judy didn't. Also, Barbra dressed up like an upper class girl but Judy and Tom wear very simple suits. So I can say that Tom and Judy represented the young generation of the U.S. As I analyzed some of members of rich young generation were sacrificed in late 1960s, Tom and Judy, as lower class young people in the U.S., also eat up by zombies. It much like the lower class young generation went to Vietnam battle in late 1960s or join in black movements, because the U.S. lost many of young people in Vietnam War and Civil movements. So I can say it definitely another symbolized characters in Night of the Living Dead. What Tom and Judy were going to do? In Night of the Living Dead, they went out because they wanted to save Coopers' daughter, Karren. Because Karren Coopers is bit by zombies, she needs medical care! But where are Tom and Judy? Where are Karren's parents? They are hiding in the cellar and refusing to go out because of fear. The young generation Tom and Judy represented in the film, going out and feed zombies with their flesh, don't you think they were actually “pay for Coopers' bill?" As Karren's parents, who need to take the responsibility to save their own child? I think the answer shouldn't be anyone else other than Karen Coopers' parents. Tom and Judy want to save a member of Coopers, but they died for their good motivation. We can easily see zombies attacking humans in death of Tom, Judy and Barbra's brother.

The ones who stay in cellar were Harry Coopers and Helen Coopers. I think there is an important plot arrangement reflecting the decision making by different groups of the U.S. In Night of the Living Dead, Coopers want everyone go to the cellar, because they consider the cellar is the best place to hide. This plot reflect the viewpoint I mentioned in the beginning of the paper, the complacent ways of Middle class. On the other side, Ben believes that going to the cellar is not the best choice because they will lose all the chances to contact with outside. This is an intellectual plot not only for the storyline, but also for reflecting the different groups' viewpoints for social issues of the U.S. Ben, as a black hero in the film, represented the newborn black power movement, he and young generation of White American(Judy, Tom, Barbra, and Johnny), connected and had positive viewpoint for social issues. In the film, they help each other and tried to get the hurt one medical care. Coopers were represented some of members of middle class Americans, they hold their own ideas for the situation and refused to take any further action. The plot of refusing to go out of the cellar, is a symbol, because this part reflect the fact that middle class of 1960s stay in their "safe" space and kept quiet when the government planned to send young kids to Vietnam. Middle class Americans didn't notice their complacent and they also refused to give a hand to black Americans to get civil right. But they didn't think they were racism, or they cannot understand why black Americans were so angry about their civil rights. Just like Coopers in the movie were not supposed to help Ben in the house, Coopers were selfish and dead for their own daughter in the cellar. Karren Coopers turned into a zombie after several hours, because she was bate by a zombie outside of the house. Her parents were the first living persons she sight, so she killed them and maybe drink up their blood. I think Romero used Coopers to satire the white people who were lack of the awareness of democracy issues in late 1960s, because they hold the certain established value for the country and when the U.S. decision 
makers did the wrong thing they just keep silent. Also, Coopers' discrimination toward Ben in the film revealed the racial segregation in 1960s. I think the ending of the Coopers was interesting because their daughter turned into zombie and killed them.

Can we consider the outcome of Coopers was a disastrous ending? Because Coopers' behavior and ideas toward the dangerous enemies and the other groups of victims predicted their outcome. God blesses good ones, so what do you think the outcome of bad ones? The director arranged Coopers killed by their daughter was also a symbolized plot because the young generation is the hope for future. But in Night of the Living Dead, young generation turned into monsters, which are beyond old generation's control. I think Coopers never consider the situation between their daughter and them, just like the American policy designers and Vietnam War. Policy designers never consider the Vietnam War turned into a nightmare for the U.S. society. Coopers, who belongs to the non-lower class white group of the U.S. are the biggest part of the country, they cannot escape from the guilt of the Vietnam War, because if they against the Vietnam War, the government cannot get enough money to afford the war and send the young citizens to South Asia. But these people, as a mainstream group, didn't say a strong enough "No", that's how the tragedy happened, much like Coopers in Night of the Living Dead, they refused to cooperate with Ben and the other people in the farmhouse, so they died under their "daughter's tooth". Instead of confronting the issue, Coopers stay in the cellar and cannot bear anyone hold different point of view. I think it is another reason why late 1960s had a radical society, because the group which had the capability to correct the government's decision keeping the old fashion in their own space with ignoring and didn't wish to give a hand to the black Americans in the U.S.

\section{Ben: the black protagonist}

The characters selected in of Night of the Living Dead are significant for the era, because the protagonist in the film is a black actor. As a series of black movements hit the U.S. in late 1960s, more and more U.S. citizens recognized that black power was growing stronger and this power would lead the civil process of the U.S. I think the director arranged Duane Jones to act black hero Ben was to symbolize the black power. Ben saves Barbra from the first zombie and he tries to protect everyone in the film at the beginning. Fighting back to the stereotypical image of black men, Ben doesn't covet Barbra even she is a blonde beauty. I believe the storyline of Night of the Living Dead arranged by Romero was to imply how black people behalf, when the country need black people to devote themselves in saving national risk. Yes, the director highlight that black people were obeying the government to join the Vietnam war. In Vietnam War, a lot of black American attend Vietnam and fight for the government of the U.S. Later in the film, audiences also discovered the other groups in the U.S. However, Ben had a sad ending in Night of the Living Dead. When zombies were under national army's control, Ben got out of the house and he was shot to die by mistake. I think Ben's situation revealed a social issue that even continued to nowadays. That's "rush to judgement". I am an international student who came to the U.S. for my undergraduate education. However, if someone tell me something like: A black guy was shot to die yesterday by mistake. I won't be surprised, because I hear a lot about it. Black American suffered from "rush to judgement" for a long time. And even in a court, this kind of thing always happened. The trial by jury sometimes judged black Americans by their skin color. I think Ben's death cry out how black American being wronged again and again in real life.

During the film Night of the Living Dead playing, audiences enjoy the processes of killing monsters and monsters attacking. Zombies in the movies are symbols of negative power, but the humans are the reason why they can attack. Some of people died for their ignorance, some of them died for the others who push them into fatal risk, and some of them died for the selfish or the other human sins. In Night of the Living Dead, zombies cannot get in the house because they fear fire, also, humans can shoot zombies' heads when they are approaching. But zombies still kill humans and make seven people in the farmhouse hurt each other. In Night of the Living Dead, monster attacking humans is not the only reason to cause casualties. Human themselves turned into cannibalism after a series of monster attacking. Why? Monsters, as the symbols of negative powers of the world, help to release humans nature. Terrified Barbra is a symbol of second generation of upper class. Tom and Judy are symbols for young generation of working class, and their sacrifices are the symbols of young generation died in Vietnam battle. Coopers were the symbols of mainstream Americans in 1960s, and their decision of hiding in the cellar is a symbol, because their action represented the fact that middle class American kept silent for Vietnam issue. Karren kills her parents in the cellar is a symbol because it reflected the disaster outcome of some Americans of middle class in 1960s. No one can escape from the judgement. Some of humans are selfish, and some of them are selflessness. Some of them are brave, but some of them are cowards. Monsters are magnifiers, which magnified humans weakness and goodness. In Night of the Living Dead, zombies are the social issues which can shaking the society of the U.S. in 1960s. The seven people in the farmhouse represented the different class of the U.S. and the different age layers of the 
American society. Furthermore, these people's responses toward the dangerous enemies are also symbols. The ritual battles between humans and monsters are never going to disappear. It reminds me a ritual hold in Bali. Rangda, an old witch, who has a horrible face, is an infant eater. She always fight with Barong, a hero. And war between them is never going to stop. It also like Yin-Yang concept in China. The evil and good depend on each other. Neither good, nor bad will conquered by forever. Everything in the world is temporary. So not only monsters attacking, but also killing the monsters are symbols, because both of them have significance. The ritual of killing monsters and monster attacking can conclude as interactions between symbols. Monsters are not always attacking but hide into the deepest dark and keep an eye on you. But again, God blesses good ones.

\section{References}

[1] Firth R. Elements of Social Organization. London and New York: Greenwood Press; 1951.

[2] Sanjek D. Twilight of the Monsters: The English Horror Film 1968-1975. Film Criticism. 1991; 16(1/2): 111-126.

[3] Ahlstrom Sydney E. The Radical Turn in Theology and Ethics: Why It Occurred in the 1960's. Annals of the American Academy of Political and Social Science. 1970; 387(1): 1-13.

[4] Pals Daniel L. Nine Theories of Religion. New York : Oxford University Press; 2014. Norman R V . Geertz, Religion, and Cultural Systems. Soundings. 1988; 71(1): 3-169. 